\title{
Environmental Influences on Essential Oils in Roots of Anemopsis californica
}

\author{
Andrea L. Medina-Holguín, Sandra Micheletto, F. Omar Holguín, \\ Jaime Rodriguez, and Mary A. O'Connell ${ }^{1}$ \\ Department of Plant and Environmental Sciences, MSC 3Q, P.O. Box 30003, \\ New Mexico State University, Las Cruces, NM 88003
}

\section{Charles Martin \\ Sustainable Agriculture Science Center, P.O. Box 159, New Mexico State University, Alcalde, NM 87511}

Additional index words. yerba mansa, piperitone, thymol, evapotranspiration, supercritical fluid extraction

\begin{abstract}
The climate conditions and chemical composition of root essential oils for 17 populations of Anemopsis californica in New Mexico were examined. The objective of this study was to observe the effect of environmental conditions and management conditions on essential oil composition in different populations of $A$. californica. Chemical concentrations of three abundant compounds-methyleugenol, thymol, and piperitone-were determined. Maximum accumulations of each compound were associated with different mean annual temperatures, precipitation, and elevation. Similar chemical profiles were detected in root samples recollected for four populations, suggesting retention of unique chemical profiles in different populations. Vegetative propagation of wild plants under cultivated conditions did not significantly alter the chemical profile of the root essential oil. The chemical concentrations for six essential oil components of $A$. californica roots were determined under field conditions with varying irrigation and nitrogen $(N)$ fertilizer regimens. The concentration of only two compounds, thymol and piperitone, was increased by increasing irrigation. The concentration of all other compounds, methyeugenol, elemicin, 1,8-cineole, and myrtenol, were independent of the irrigation rates and $\mathrm{N}$ fertilizer rates used in the study. These results suggest that the chemical variability observed among different populations of A. californica is primarily genetically controlled and the environmental conditions in New Mexico are conducive to the production of this medicinal plant as a high-value crop.
\end{abstract}

Anemopsis is one of five genera belonging to the Saururaceae family. The genus contains a single species, A. californica (Nutt.) Hook. and Arn. (Houttuynia californica Benth. et Hook.), commonly known as yerba mansa. For generations, Hispanics and Native American tribes of the Southwest have relied on A. californica for its healing properties using both roots/rhizomes and leaves. Traditional uses vary widely and include treatment of cold and flu symptoms, pain and inflammation, venereal disease, and uterine cancer (Artschwager-Kay, 1996; Moore, 1989). Recent studies demonstrate that $A$. californica does indeed possess antimicrobial (Medina et al., 2005) and chemotherapeutic properties (Medina-Holguín, 2006).

Environmental factors, including cultivation, temperature, moisture, and soil, appear to have an impact on volatile compound

\footnotetext{
Received for publication 26 Apr. 2007. Accepted for publication 24 June 2007.

This work was supported in part by the NM Agricultural Experiment Station, USDA CSREES grant 200634387-15885, and National Institutes of Health grants NIGMS GM61222, S06 GM08136, and NCI U56 CA96286.

${ }^{1}$ To whom reprint requests should be addressed; e-mailmoconnel@nmsu.edu.
}

production in medicinal and herb crops (Boira and Blanquer, 1998; Bowes and Zheljazkov, 2004, 2005; Falzari et al., 2006; Gotsiou et al., 2002; Ložiene and Venskutonis, 2005; Medina et al., 2005). The concentration of individual volatile compounds in Thymus piperella responds to a variety of environmental factors independently of other compounds in the whole oil (Boira and Blanquer, 1998). In fennel, there were cultivar-specific responses to planting dates and, as expected, cultivar-specific chemical profiles in the essential oils (Bowes and Zheljazkov, 2005).

Anemopsis californica is collected throughout the southwestern part of North America and used by healers to treat a variety of ailments (Medina et al., 2005), yet the variability and stability of the chemical composition of populations of $A$. californica used for medicine are largely unknown. In addition, the natural habitat of $A$. californica is under increasing pressure as a result of expanding urban development. Sources for healthy plants, free of industrial toxins, are becoming scarce. Coupled with these phenomena is the ever-growing demand for standardized herbal remedies. A. californica has potential as a high-value alternative crop for small-scale farmers (Falk et al., 1999). In a field study conducted by Kleitz et al. (2003), an A. californica crop yielded $4.36 \mathrm{t}$ dry root/ha; at current prices of at least $\$ 18$ / $\mathrm{kg}$, this is well over twice the rate of positive return needed for most small farms. Hayden (2006) has investigated the aeroponic production of $A$. californica and shown that although the concentration of essential oil components is higher in field-grown plants, the plant densities possible in an aeroponic system supports continued use of this management approach.

We collected $A$. californica root tissue from 17 populations growing along the Rio Grande in New Mexico. Variables such as temperature, annual rainfall, and cultivation have been examined for their effects on the abundance of three essential oil components: piperitone, thymol, and methyeugenol (Fig. 1). Stability of chemical composition in wild populations over time, and the effect of cultivation, was also tested as well as the effect of irrigation and fertilizer treatments on the abundance of six essential oil components: monoterpenes, piperitone, thymol, myrtenol, and 1,8-cineole; and phenylpropanoids, methyeugenol, and elemicin (Fig. 1). The objective of this study was to observe the effect of environmental conditions and management conditions on essential oil composition in different populations of A. californica.

\section{Materials and Methods}

Plant material. Anemopsis californica plants from 17 distinct populations growing in New Mexico were collected in Fall 2001; four of the populations (Velarde, Rio Grande Nature Center, Mesilla Valley, and Greenhouse) were recollected in Fall 2004. Elevation, latitude, and longitude were determined using a Garmin (Olanthe, KS) E-trex personal navigator. Coordinates will not be published in the interest of protecting the populations. Root/rhizome samples from three individuals were collected from each population and stored on ice for transport to the laboratory. The roots were dried at room temperature, ground in an industrial blender, and stored at $-80{ }^{\circ} \mathrm{C}$ until extraction. Roots were considered dried when there was no further weight

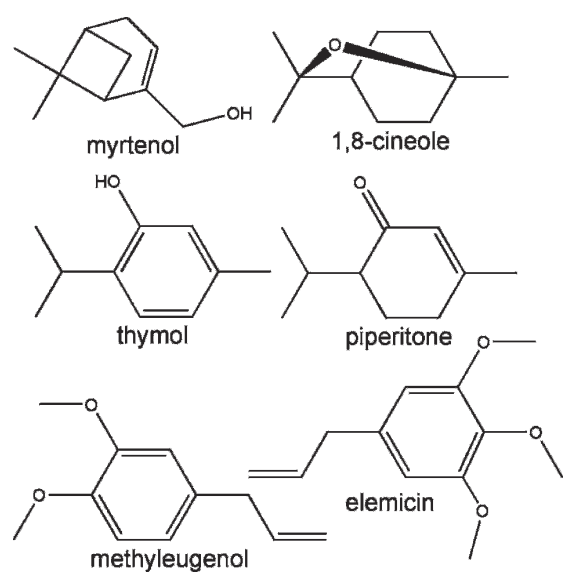

Fig. 1. Chemical structures of essential oil compounds characterized in A. californica root extractions. 
loss detected with reweighing. This time varied for the samples but typically roots were dried for 3 months.

Anemopsis californica plants were propagated by root division. Anemopsis californica (Mesilla Valley population) from Dona Aña County, NM (elevation, $1198 \mathrm{~m}$ ) was harvested in Aug. 1999 and cultivated in a New Mexico State University campus greenhouse (Greenhouse population) in Metro Mix 360 (Greenhouse \& Garden Supply Inc., Albuquerque, NM), fertilized with Osmocote 14-14-14, and watered daily using drip irrigation. Anemopsis californica (Alcalde Wild population) from Rio Arriba County, NM (elevation, $1748 \mathrm{~m}$ ) was harvested in 1999 and grown in a managed field for 2 years at the Sustainable Agriculture Science Center in Alcalde, NM (Alcalde Field population). The field was irrigated approximately weekly.

Two replicate field trials were carried out at the Sustainable Agriculture Science Center of New Mexico State University in Alcalde, NM, during the 2002 to 2004 growing seasons. Dormant cohorts of A. californica crowns, obtained from a field nursery at the station, were dug up by hand in late March of 2002 and 2003, respectively. Crowns were transplanted into furrows at $30-\mathrm{cm}$ spacing, with $\approx 91 \mathrm{~cm}$ between furrow centers. The plantings were grown for two seasons, the first season to establish the plants and the second season to apply the treatment levels. Treatment phases were initiated when crowns broke dormancy and leaves were fully emerged; drip irrigation $[25 \%, 50 \%$, and $100 \%$ of daily pan evapotranspiration rate $(\mathrm{PET})]$, and nitrogen $(\mathrm{N})$ fertilizer $[0,4.6$, and $9.2 \mathrm{~kg} / \mathrm{ha}$ as $\left.\mathrm{Ca}\left(\mathrm{NO}_{3}\right)_{2}\right]$. Water volume applied to each treatment level was determined using Penman-Monteith equations, standard equations for calculating reference evapotranspiration (Sammis et al., 1985). There were $180-\mathrm{cm}$ wide border alleyways separating the different irrigation treatments to prevent lateral movement of irrigation water between treatments. Nitrogen was applied in split applications; half of the indicated amount was applied in early June and the remaining half was applied 2 weeks later. The trial was replicated three times across the field for a total of 27 treatment plots in each growing cycle. Before planting, crowns were washed, blotted to remove surface moisture, and individually weighed to obtain initial crown fresh weights. Crown/root dry matter weights for each plant were determined at the end of the growing season (November).

Plant extractions and analyses. The conditions for supercritical fluid extraction (SFE) and gas chromatography/mass spectrometry (GC/MS) analyses were essentially as described by Medina et al. (2005). For SFE extraction, $0.5 \mathrm{~g}$ of ground root tissue was loaded into thimbles for extraction in an ISCO SFX3560 (Isco, Lincoln, NE). The extraction was vented into a tube containing $10 \mathrm{~mL}$ of methanol to trap the essential oil components as the $\mathrm{CO}_{2}$ bubbled off. Extracts were analyzed by GC/MS using a Varian
(Palo Alto, CA) model 3400 GC with a DB-5 column $(30 \mathrm{~m} \times 0.25$-mm fused silica capillary, $0.25-\mu \mathrm{m}$ film thickness) coupled to an ion trap mass spectrometer (EI, $70 \mathrm{eV})$. Comparisons of mass spectra with authentic standards were used to identify the peaks. Calibration curves with authentic standards were used to quantify the abundance of each compound.

Statistical analysis. Statistical analysis software, Excel XLSTAT 2006 (Microsoft, Redmond, WA), was used to perform analysis of variance (ANOVA). The ANOVA was run on our field experiment set up as a complete randomized experimental design with two factors, $\mathrm{N}$ and water availability. Each factor had three treatment levels; each year was analyzed separately as a result of significant differences in climate conditions.

Environmental data collection. Mean monthly temperature (MNTM) and total monthly precipitation (TCPC) from 2003 and 2004 were obtained from the National Oceanic and Atmospheric Administration weather station database (NOAA, 2005). Weather stations were located by the nearest elevation, latitude, and longitude that corresponded to each respective population. This resulted in data collection from 17 different stations distributed among the counties of the A. californica populations. MNTM was used to calculate mean annual temperature (in degrees Celsius), and TCPC was used to calculate mean annual rainfall (in centimeters) (years 1999 to 2001). Contour maps were generated using SigmaPlot 8.0 (Systat Software, San Jose, CA). Monthly data were reported for the Alcalde, NM, weather station (elevation, $1731 \mathrm{~m}$; lat. $36^{\circ} 05^{\prime} \mathrm{N}$; long. $106^{\circ} 03^{\prime} \mathrm{W}$ ) for the growing seasons 2003 and 2004.

\section{Results}

Root tissue from 17 populations of A. californica was collected in Fall 2001. Populations were located at altitudes between 1198 and 1793 m. Anemopsis californica

Table 1. Chemical variability of New Mexico A. californica populations. ${ }^{\mathrm{z}}$

\begin{tabular}{|c|c|c|c|c|}
\hline $\begin{array}{l}\text { New Mexico } \\
\text { Populations }\end{array}$ & $\begin{array}{l}\text { Elevation } \\
\text { (m) }\end{array}$ & $\begin{array}{l}\text { Piperitone } \\
(\mu \mathrm{g} / \mathrm{g})\end{array}$ & $\begin{array}{l}\text { Thymol } \\
(\mu \mathrm{g} / \mathrm{g})\end{array}$ & $\begin{array}{c}\text { Methyleugenol } \\
(\mu \mathrm{g} / \mathrm{g})\end{array}$ \\
\hline Pojoaque A & 1793 & $42 \pm 30$ & $178 \pm 110$ & $19,284 \pm 8880$ \\
\hline Pojoaque B & 1788 & $84 \pm 20$ & $254 \pm 10$ & $20,535 \pm 1860$ \\
\hline Velarde & 1764 & $437 \pm 220$ & $905 \pm 340$ & $19,447 \pm 4080$ \\
\hline Alcalde Field & 1748 & $512 \pm 470$ & $854 \pm 70$ & $13,804 \pm 1270$ \\
\hline Alcalde Wild & 1727 & $266 \pm 220$ & $537 \pm 430$ & $10,876 \pm 4120$ \\
\hline San Juan Domestic & 1719 & $26 \pm 50$ & $208 \pm 230$ & $4165 \pm 1690$ \\
\hline Ranchitos & 1719 & $29 \pm 10$ & $93 \pm 20$ & $11,270 \pm 560$ \\
\hline San Pedro & 1712 & $116 \pm 100$ & $183 \pm 120$ & $18,844 \pm 4300$ \\
\hline Española & 1709 & $18 \pm 10$ & $214 \pm 20$ & $14,967 \pm 940$ \\
\hline Faywood Hotsprings & 1538 & $56 \pm 60$ & $318 \pm 160$ & $14,156 \pm 10,570$ \\
\hline City of Rocks & 1531 & $9.0 \pm 0.0$ & $58 \pm 50$ & $9078 \pm 1660$ \\
\hline RGNC & 1520 & $314 \pm 110$ & $478 \pm 80$ & $25,148 \pm 8570$ \\
\hline Chaparral Horse Ranch & 1506 & $55 \pm 40$ & $438 \pm 370$ & $20,971 \pm 7560$ \\
\hline Bosque Del Apache & 1385 & $38 \pm 40$ & $175 \pm 180$ & $4068 \pm 2440$ \\
\hline Mesilla Valley & 1198 & $99 \pm 20$ & $383 \pm 50$ & $23,086 \pm 7300$ \\
\hline Greenhouse & 1198 & $133 \pm 80$ & $297 \pm 70$ & $23,283 \pm 1580$ \\
\hline Picacho & 1198 & $48 \pm 20$ & $458 \pm 220$ & $24,680 \pm 3960$ \\
\hline
\end{tabular}

${ }^{\mathrm{z}}$ Average abundance of piperitone, thymol, and methyleugenol in roots of 17 populations of $A$. californica $(\mathrm{n}=3$, concentration in $\mu \mathrm{g} / \mathrm{g}$ dried root).

$\mathrm{RGNC}=$ Rio Grande Nature Center was regularly located near a water source, although water sources may dry out periodically throughout the year. The three most abundant essential oil components were quantified in the 17 populations (Table 1).

There was a great deal of variability among the 17 populations in the abundance of the three major components. Piperitone concentrations ranged from 9 to $512 \mu \mathrm{g} / \mathrm{g}$ dry wt root, thymol from 58 to $905 \mu \mathrm{g} / \mathrm{g}$, and methyleugenol from 4068 to $25,148 \mu \mathrm{g} / \mathrm{g}$. Methyleugenol was the most abundant compound and usually represented greater than $95 \%$ of the essential oil content. Distinct chemical profiles were identified and different climate conditions were associated with optimal accumulation of each of three different essential oil components (Fig. 2).

Elevation (in meters), mean annual temperature (in degrees Celsius), and mean annual rainfall (in centimeters) for each of the 17 sites of collection were plotted against compound concentrations to observe correlations between chemistry of $A$. californica root tissue and environmental variables (Fig. 2). Temperature and elevation as environmental factors were inversely correlated with one another; mean annual temperatures increased with decreasing elevation. In New Mexico, the southern region was hot and dry, whereas the northern region was cooler with more precipitation.

Each compound had a unique profile for accumulation as a function of elevation, temperature, and precipitation. Maximum accumulation of methyleugenol occurred at elevations below $1700 \mathrm{~m}$, mean annual temperatures between $12{ }^{\circ} \mathrm{C}$ and $15{ }^{\circ} \mathrm{C}$, and precipitation levels below $25 \mathrm{~cm} /$ year. In contrast, thymol levels were maximal in plants grown at elevations above 1750, temperatures below $12{ }^{\circ} \mathrm{C}$, and precipitation levels $26 \mathrm{~cm} /$ year. The piperitone profiles were similar to thymol, but there was elevated accumulation of piperitone levels in plants at slightly warmer lower elevation locations.

Many herbalists have suggested that medicinal plants are not as potent when 

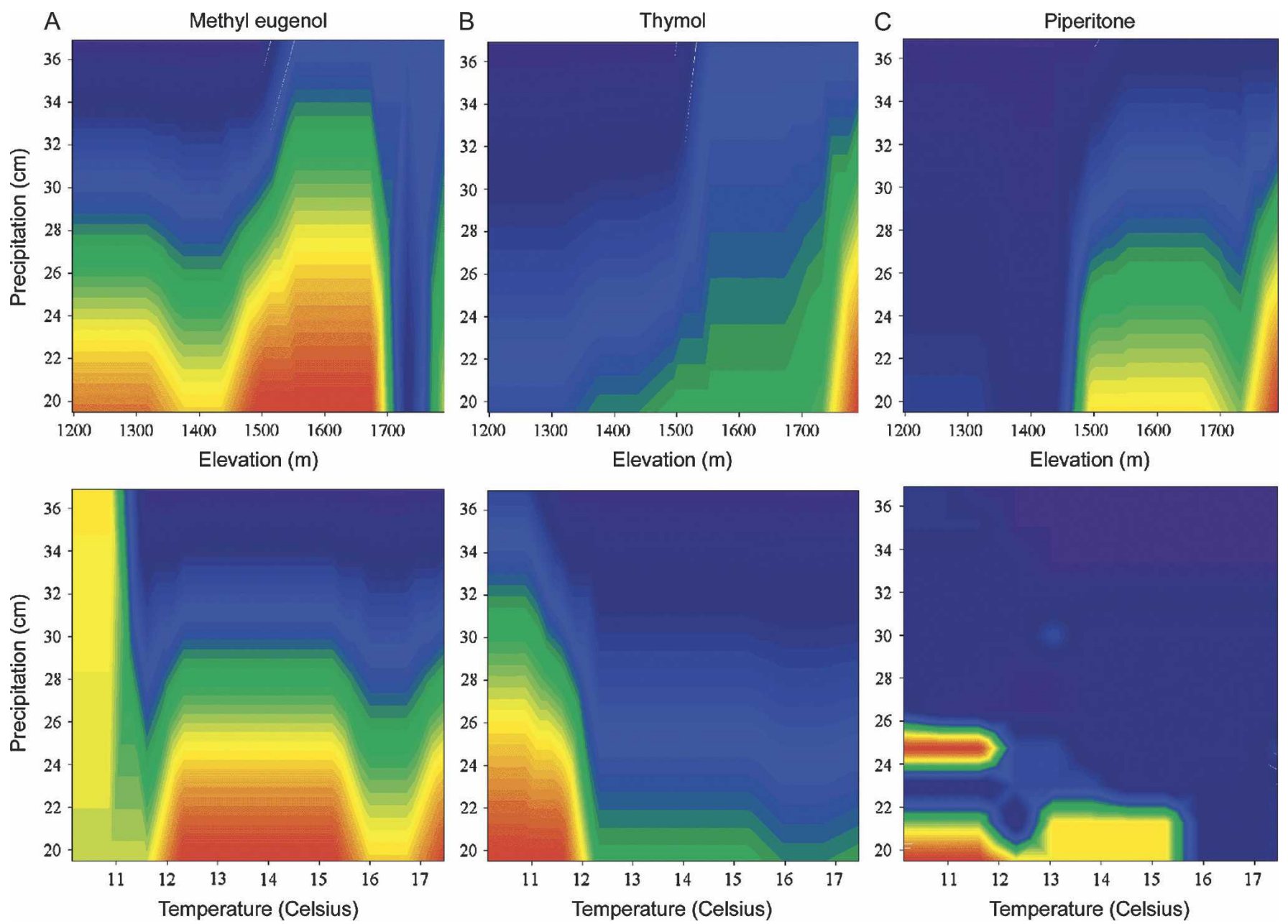

Fig. 2. Correlation between elevation, temperature, and precipitation and accumulation of select compounds in roots of different populations of New Mexico A. californica. Levels for (A) methyleugenol, (B), thymol, and (C) piperitone plotted as a function of total annual precipitation versus elevation (upper row) or mean annual temperature (lower row). The color scale reflects abundance with red indicating maximal amounts and blue lowest amount.

grown in a cultivated setting compared with wildcrafted samples. To directly test this hypothesis, we compared the levels of compounds in plants clonally propagated and cultivated for 2 years under controlled settings with levels in the uncultivated donor population growing at the original collection site. In Table 1, these analyses are presented in comparisons between "Alcalde Field" and "Alcalde Wild" and "Mesilla Valley" and "Greenhouse." These populations represented the northern (Alcalde) and southern (Mesilla Valley) regions of the state. There were no statistically significant differences, based on a two-tailed $t$ test, in the accumulation of any of the three compounds as a result of cultivation.

To determine whether $A$. californica populations retain their chemical profiles over time, four populations - Velarde, Rio Grande Nature Center (RGNC), Mesilla Valley, and Greenhouse-were recollected in Fall 2004. We expected that at three of these sites, there would be differences in environmental conditions during the period 2001 to 2004 . The greenhouse population had the most stable environmental conditions. The chemical profiles of tissue collected in 2001 and 2004 were compared using a two-sample $t$ test $(\alpha=$

Table 2. Recollection and analysis of selected $A$. californica populations. ${ }^{2}$

\begin{tabular}{|c|c|c|c|c|c|c|}
\hline \multirow[b]{2}{*}{ Populations } & \multicolumn{2}{|c|}{ Piperitone } & \multicolumn{2}{|c|}{ Thymol } & \multicolumn{2}{|c|}{ Methyleugenol } \\
\hline & 2001 & 2004 & 2001 & 2004 & 2001 & 2004 \\
\hline Velarde & 437 & 254 & 905 & 943 & 19,447 & $32,723^{y}$ \\
\hline RGNC & 314 & 132 & 478 & $1116^{y}$ & 25,148 & 39,361 \\
\hline Mesilla Valley & 99 & 200 & 383 & $1117^{y}$ & 23,086 & 51,583 \\
\hline Greenhouse & 133 & 107 & 297 & $710^{y}$ & 23,283 & $43,228^{y}$ \\
\hline
\end{tabular}

${ }^{\mathrm{z} A v e r a g e}$ abundance of piperitone, thymol, and methyleugenol in roots of four populations of A. californica collected in 2001 and again in $2004(\mathrm{n}=3$, concentration in $\mu \mathrm{g} / \mathrm{g}$ dried root).

${ }^{\text {y }}$ Significant between-year differences at $P \leq 0.05$.

0.05) of the three compounds in each population. The results of this comparison revealed significant increases in the concentration of thymol in the RGNC, Mesilla Valley, and Greenhouse populations in 2004 versus 2001. Methyleugenol concentrations significantly increased in the Velarde and Greenhouse populations. There was no significant difference in piperitone content in any population between 2001 and 2004. In both years, the Velarde population remained the population with the highest levels of piperitone and the lowest levels of methyleugenol. In general, the wild and greenhouse populations of Mesilla Valley retained the highest levels of methyleugenol and the lowest levels of piperitone and thymol for both years of analysis.
Analysis of tissues that were recollected at selected sites after 3 years revealed the stability of chemical profiles within a population as well as the retention of unique chemical profiles between populations (Table 2).

Anemopsis californica plants were grown in field trials for 2 years after transplanting as small crowns. This plant usually propagates vegetatively by runners in riverbank areas. Equivalent-sized crowns were used to establish all of the plants in the different treatment blocks. The mean monthly temperature and monthly precipitation are presented for years 2003 and 2004 at the field site (Fig. 3). These were the years of treatment in each replicated 2 -year growth trial. The average monthly temperatures were the same in both treatment 
years, but the amount of precipitation in 2004 was higher than in 2003.

Plant samples were collected after the plants had gone dormant in the late fall and included the root, rhizome, and crown. After two seasons of growth, the average root biomass per plant was $66.9 \pm 24.6 \mathrm{~g}$ in 2003 and $71.2 \pm 22.2 \mathrm{~g}$ in 2004. Nitrogen fertilizer had no effect on the dry matter yield in either season (Table 3). However, irrigation positively influenced the dry matter yield. This increase was the most pronounced in the harvest for 2003 but was also significant for 2004 (Table 3; Fig. 4A). Dry matter yield increased close to twofold with irrigation at $100 \%$ PET in each year.

In this study, the abundance of six compounds were quantified in each sample: 1,8cineole, myrtenol, piperitone, thymol, methyleugenol, and elemicin (Table 4). Irrigation and $\mathrm{N}$ fertilizer rates had no effect on the abundance of the essential oil compounds, except piperitone and thymol (Table 3 ). In year 2003, the abundance of both of these compounds was positively influenced by irrigation. Thymol levels increased 1.5 -fold and piperitone levels increased 12-fold with irrigation at $100 \%$ PET (Fig. 4B-C).

\section{Discussion}

The climate in select locations in New Mexico is favorable for essential oil accumulation in A. californica root tissue. In general, optimal environmental conditions for essential oil production in $A$. californica are $11.67{ }^{\circ} \mathrm{C}$ to $15.56{ }^{\circ} \mathrm{C}$ and less than $25.4 \mathrm{~cm}$ of annual rainfall. Different essential oil compositions were observed among the populations collected throughout the state. Optimal conditions for oil production reflect the natural climate conditions in much of New Mexico; 1971 to 2000 annual averages were calculated as $13.8^{\circ} \mathrm{C}$ and $24.5 \mathrm{~cm}$ precipitation using NOWData for New Mexico (NOAA, 2005).

In the crop management study, we demonstrated that irrigation and fertilizer have only modest effects on the chemical composition of $A$. californica root essential oils (Table 4). Only two of six essential oil components varied as a function of irrigation rates, and then only in one of the 2-year studies. There was more rain in 2004 than in 2003 (Fig. 3), so plants irrigated to the lower PET levels and harvested in 2004 probably did not experience as severe a water deficit stress as those in 2003. Irrigation rates had a significant effect on root biomass yield dry weight (Table 3). Plants responded to the management treatments with an overall increase in biomass production and no dilution or alteration in chemical composition. Populations selected for production of specific chemotypes in a crop setting are likely to reliably produce those chemical profiles with little to no environmental effects on chemical composition.

Analysis of tissues that were recollected at selected sites after 3 years revealed the stability of chemical profiles within a population as well as the retention of unique
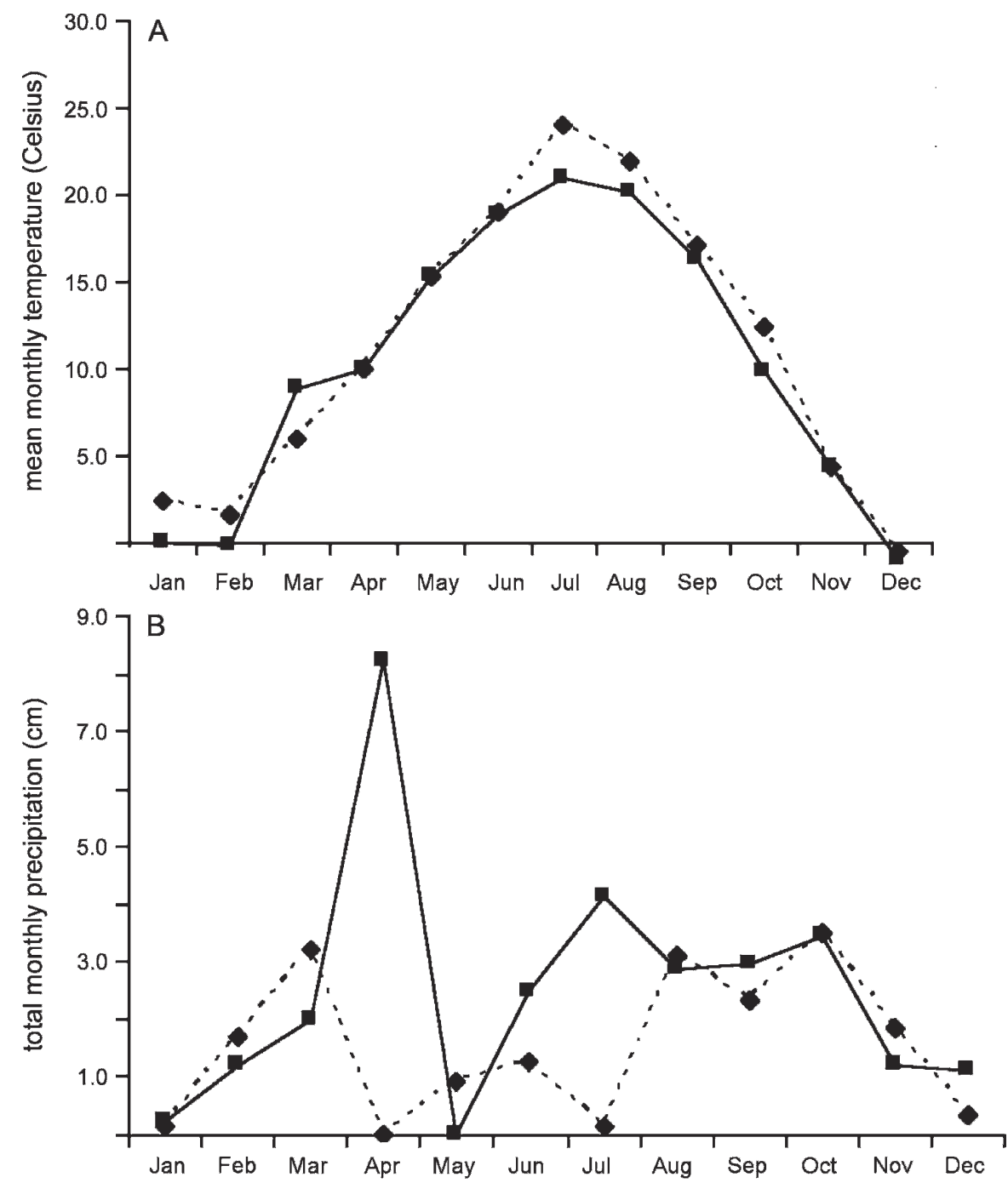

Fig. 3. Temperature and precipitation at the Sustainable Center, Alcalde, NM. (A) Mean monthly temperature; $(\mathbf{B})$ total monthly precipitation. Solid line $=2003$; dashed line $=2004$.

Table 3. Analysis of variance on A. californica dry root biomass accumulation and abundance of essential oil components in plants grown under controlled irrigation and $\mathrm{N}$ fertilizer at Alcalde, NM.

\begin{tabular}{|c|c|c|c|}
\hline Source & $\mathrm{DF}$ & Mean Squares & $P$ \\
\hline \multicolumn{4}{|c|}{ Yield (root dry matter 2003) } \\
\hline PET (\%) & 2 & 4511.618 & $2 \times 10^{-4 z}$ \\
\hline $\mathrm{N}(\mathrm{kg} / \mathrm{ha})$ & 2 & 145.738 & 0.642 \\
\hline PET $(\%) * \mathrm{~N}(\mathrm{~kg} / \mathrm{ha})$ & 4 & 149.159 & 0.761 \\
\hline \multicolumn{4}{|c|}{ Yield (root dry matter 2004) } \\
\hline PET (\%) & 2 & 2966.414 & $0.001^{\mathrm{z}}$ \\
\hline $\mathrm{N}(\mathrm{kg} / \mathrm{ha})$ & 2 & 152.703 & 0.615 \\
\hline $\operatorname{PET}(\%) * \mathrm{~N}(\mathrm{~kg} / \mathrm{ha})$ & 4 & 264.636 & 0.503 \\
\hline \multicolumn{4}{|c|}{ Piperitone ( $\mu \mathrm{g} / \mathrm{g}$ root dry wt, 2003) } \\
\hline PET (\%) & 2 & 837.086 & $0.040^{z}$ \\
\hline $\mathrm{N}(\mathrm{kg} / \mathrm{ha})$ & 2 & 170.467 & 0.469 \\
\hline PET $(\%)^{*} \mathrm{~N}(\mathrm{~kg} / \mathrm{ha})$ & 4 & 575.150 & 0.066 \\
\hline \multicolumn{4}{|c|}{ Thymol $(\mu \mathrm{g} / \mathrm{g}$ root dry wt, 2003$)$} \\
\hline PET $(\%)$ & 2 & $147,584.303$ & $0.041^{\mathrm{z}}$ \\
\hline $\mathrm{N}(\mathrm{kg} / \mathrm{ha})$ & 2 & $27,660.223$ & 0.502 \\
\hline $\operatorname{PET}(\%) * \mathrm{~N}(\mathrm{~kg} / \mathrm{ha})$ & 4 & $14,840.402$ & 0.817 \\
\hline
\end{tabular}

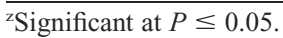

$\mathrm{N}=$ nitrogen; $\mathrm{DF}=$ degrees of freedom; $\mathrm{PET}=$ pan evapotranspiration.

chemical profiles among populations. Based on these studies, we can expect genetic influences to have a significant effect on variability in New Mexico A. californica populations. High oil-yielding populations such as Mesilla Valley A. californica, which retain their chemical profiles through cultivation and changing environmental conditions, may be reliable seed sources for farmers seeking a high-value crop.

Headspace analysis of Origanum microphyllum performed on samples from five wild 

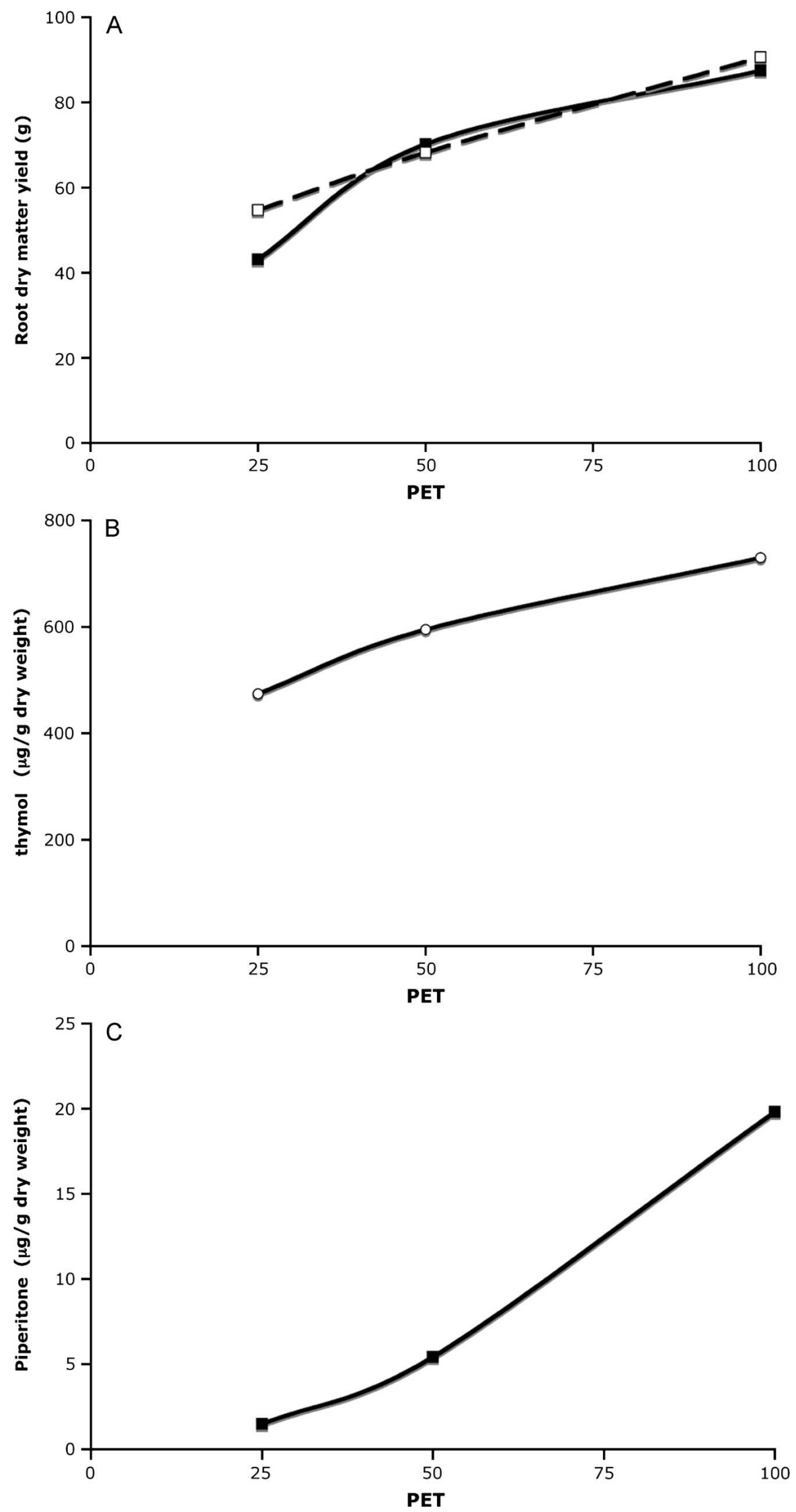

Fig. 4. Effect of pan evapotranspiration (PET) on root biomass and abundance of piperitone and thymol in A. californica roots. (A) Average dried root, rhizome, and crown biomass (g) per plant at the indicated irrigation rate $(25 \%, 50 \%$, or $100 \%$ percent of PET; solid line $=2003$; dashed line $=2004$. (B) Average thymol accumulation in dried plant samples at the indicated irrigation rates (2003). (C) Average piperitone accumulation in dried plant samples at the indicated irrigation rates (2003).
Table 4. Concentration of essential oil components in roots of $A$. californica grown under controlled irrigation and nitrogen fertilizer. ${ }^{\mathrm{z}}$

\begin{tabular}{lrr}
\hline Essential Oil & & \\
Component & \multicolumn{1}{c}{} & \multicolumn{1}{c}{2004} \\
\hline 1,8-cineole & 27.08 & 10.77 \\
Myrtenol & 4.96 & 19.61 \\
Piperitone & $8.91^{\mathrm{y}}$ & 25.41 \\
Thymol & $599.63^{\mathrm{y}}$ & 802.50 \\
Methyleugenol & $39,543.39$ & $31,503.80$ \\
Elemicin & 793.59 & 668.61 \\
\hline
\end{tabular}

${ }^{\mathrm{z}}$ Dried roots were extracted by SFE and composition determined using GC-MS. Average abundance is reported $(\mu \mathrm{g} / \mathrm{g}$ dried root) for samples collected in 2003 and 2004 after 2 years of growth. ${ }^{\text {y }}$ Significant differences at $P \leq 0.05$ in response to PET.

SFE $=$ supercritical fluid extraction; GC-MS = gas chromatography/mass spectrometry; $\mathrm{PET}=$ pan evapotranspiration.

populations and compared with vegetative clones after 1 year of cultivation revealed a slight decrease in abundance of specific compounds and greater variation in lower abundance compounds. However, the general composition remained largely unchanged (Gotsiou et al., 2002). Ložienė and Venskutonis (2005) found that Thymus pulegioides clones either preserved their composition after a sudden change in environment or had a significant change but regained a composition similar to the original populations after the fifth generation. These results are similar to our current results (Table 1) as well as our earlier findings in A. californica studies in which greenhouse-reared clones of a wild population retained a leaf volatile composition nearly identical to the parent plants over 2 years (Medina et al., 2005).

Growing under cultivated conditions appears to have little effect on the chemical composition of $A$. californica populations in Alcalde and Mesilla Valley. No statistically significant differences in the most abundant compounds in the root and rhizome were observed after 2 years of cultivation under greenhouse conditions for the Mesilla Valley population or agricultural field conditions for the Alcalde population. All of these studies suggest that the essential oil compositions in different populations are stable and the different chemical compositions are likely to be the result of primarily genetic differences with some variability in the result of environmental or climatic conditions.

\section{Literature Cited}

Artschwager-Kay, M. 1996. Healing with plants in the American and Mexican West. University of Arizona Press, Tucson, AZ.

Boira, H. and A. Blanquer. 1998. Environmental factors affecting chemical variability of essential oils in Thymus piperella L. Biochem. Syst. Ecol. 26:811-822.

Bowes, K.M. and V.D. Zheljazkov. 2004. Factors affecting yields and essential oil quality of Ocimum sanctum L. and Ocimum basilicum L. cultivars. J. Amer. Soc. Hort. Sci. 129:789-794.

Bowes, K.M. and V.D. Zheljazkov. 2005. Essential oil yields and quality of fennel grown in Nova Scotia. HortScience. 39:1640-1643. 
Falk, C.L., H. van Voorthuizen, M.M. Wall, S.J. Guldan, C.A. Martin, and K.M. Kleitz. 1999. Costs and returns of growing selected medicinal herbs in New Mexico indicate positive return to land and risk likely. HortTechnology 9:681-686.

Falzari, L.M., R.C. Menary, and V.A. Dragar. 2006. Optimum stand density for maximum essential oil yield in commercial fennel crops. HortScience. 41:646-650.

Gotsiou, P., G. Naxakis, and M. Skoula. 2002. Diversity in the composition of monoterpenoids of Origanum microphyllum (Labiatae). Biochem. Syst. Ecol. 30:865-879.

Hayden, A.L. 2006. Aeroponic and hydroponic systems for medicinal herb, rhizome, and root crops. HortScience. 41:536-538.
Kleitz, K.M., M.M. Wall, C.L. Falk, C.A. Martin, M.D. Remmenga, and S.J. Guldan. 2003. Yield potential of selected medicinal herbs grown at three plant spacings in New Mexico. HortTechnology 13:631-636.

Ložiene, K. and P.R. Venskutonis. 2005. Influence of environmental and genetic factors on the stability of essential oil composition of Thymus pulegioides. Biochem. Syst. Ecol. 33:517-525.

Medina, A.L., M.E. Lucero, F.O. Holguín, R.E. Estell, J.J. Posakony, J.A. Simon, and M.A. O'Connell. 2005. Composition and antimicrobial activity of Anemopsis californica leaf oil. J. Agr. Food Chem. 53:8694-8698.

Medina-Holguín, A.L. 2006. Population analysis of Anemopsis californica in New Mexico: Searching for anti-cancer activity in the desert.
PhD Thesis. New Mexico State University, Las Cruces, NM.

Moore, M. 1989. Medicinal plants of the desert and canyon west: A guide to identifying, preparing, and using traditional medicinal plants found in the deserts and canyons of the West and Southwest. Museum of New Mexico Press, Santa Fe, NM.

National Oceanic and Atmospheric Administration (NOAA). 2005. MNTM and TCPC retrieved 2 Nov. 2005 from the online database $<\mathrm{http} / /$ www.nws.noaa.gov/>.

Sammis, T.W., C.L. Mapel, D.G. Lugg, R.R. Lansford, and J.T. McGuckin. 1985. Evapotranspiration crop coefficients predicted using growing-degree-days. Trans. Amer. Soc. Agr. Eng. 28:773-780. 